\title{
Why Leading for Transformation in South African Township Secondary Schools Fails: Views from Deputy Principals
}

\author{
Patrick Mafora \\ Department of Educational Leadership and Management, University of South Africa \\ Email: pmafora@unisa.ac.za
}

\section{Doi:10.5901/mjss.2013.v4n3p687}

\section{Abstract}

This article reports selected findings of a qualitative multi case study on transformative leadership in Soweto secondary schools in South Africa. The scope of this article is restricted to an examination of deputy principals' views regarding why leading for transformation is not successful in South African township secondary schools. Data were collected from two secondary schools through in-depth one on one semi-structured interviews. Data analysis was based on Tesch's steps for open coding. Findings point to a myriad of barriers that include: principals' leadership style; bureaucracy, limited district office support and, teacher resistance. The article argues that the bureaucratic structure of schools entrenches the status quo and that the transformation of township secondary schools will remain elusive if the associated barriers are not addressed.

Keywords: collective leadership; deputy principals; educational change; secondary schools; South Africa

\section{Introduction}

The transformation of the education system becomes inevitable when nations undergo political changes (VillegasReimers, 2003; Guskey, 2002). However, because transformation implies a fundamental paradigm shift in social values, principles and philosophy (Karlsson, 2005), the educational reforms that are envisaged do not always take root immediately following the promulgation of new policies or legislation. Sometimes, the implementation of reforms just fizzles out. With regard to educational reforms in South Africa, Grobler, Bisschoff and Beeka (2012) opine that the bureaucratic structure of the education system militates against taking rapid decisions that are called for when rapid change is introduced. Almost two decades into the new political dispensation in South Africa, and the proliferation of progressive policies and legislation, some undemocratic and inequitable practices are still evident in the education system. These are commonly attributed to the ingrained effects of apartheid (Brown, 2006a; Karlsson, 2005, Gallie, Sayed \& Williams, 1997). For instance, differences between schools that were differentially funded and resourced because they served different race groups are still discernible (Brown, 2006a). Township schools still serve black African learners only and still lag behind, reflecting attributes associated with socio-economic disadvantage. There is a one way exodus of learners from township schools to former Model C schools in suburbs (Msila, 2009, 2005; Brown, 2006a; Gallie, Sayed \& Williams, 1997). This feeds and entrenches racial stereotypes with regard to teacher professionalism and efficiency, and school management effectiveness. Given the implied negativity of perceptions of poor quality education in township schools (Gallie, Sayed \& Williams, 1997), how township school leaders perceive and experience leading transformation warrants investigation.

\subsection{Study context and background}

This case study was a follow up on three schools included in a descriptive multi-site case study on transformative leadership for social justice in township secondary schools. This article is, however, restricted to two schools only. Data from the third school were discarded because its leadership changed before the completion of the initial study. These two secondary schools, Alpha and Omega (these are pseudonyms) are located in the same low socio-economic neighbourhood and are classified as quintile one schools, where parents are charged no fees. The living conditions in this neighbourhood are described in detail elsewhere (Mafora, 2013) and shall not be outlined in this article. The schools have a similar executive management structure. Each school has a principal, two deputy principals and, seven to eight heads of departments. The average staff complement of each school is 36 teachers and eight administrative support staff, while pupil enrolment averages 1200 per school year. Both these schools have male principals and one of the deputy principals 
is male while the other is female. All pupils and teachers are black Africans.

South African townships schools are generally considered to be dysfunctional (Mangena, 2012; Mokonyane, 2011; Williams, 2011; Pandor, 2006). The schools are bereft of what Karlsson (2005) regards as evidence of a transformed school environment in the context of South African public school system - materially improved teaching and learning facilities, safety practices, materially secure learning conditions, inclusivity and the promotion of tolerance and diversity. Without concerted transformation efforts, these schools will continue to lag behind and make little difference in the lives of learners and the school community. The schools face a myriad of challenges that suggest a need for questioning and changing the status quo. Some of the key challenges confronting these schools, but which are not restricted to township schools, include:

- Poor quality of teaching and learning (Jansen, 2013; Motala, 2011; Mokonyane, 2011; Soudien, 2007; Brown, 2006a);

- Bureaucratic and ineffective leadership and management (Brown, 2006a; Grant, 2006; Mathonsi, 2001);

- Poor state of infrastructure and limited resources (Motala, 2011; Moloi, 2010; Brown, 2006a);

- Violence, physical abuse and negative social attitudes (Motala, 2011; Mokonyane, 2011; Gallie, Sayed \& Williams, 1997);

- Low level of parental participation (Mangena, 2012; Motala, 2011; Van Wyk, 2007); and

- Increasing poverty in the school community (Moloi, 2010; Brown, 2006a).

Conceived of against this background of transformation challenges, the focus of this article, which was drawn from a bigger study, was to examine what deputy principals perceive as factors that account for the failure of transformation in township secondary schools. It was hoped insight from the study could contribute to efforts to transform these schools from within.

I acknowledge the centrality of the principal in managing and leading educational activities in schools (Van Deventer \& Kruger, 2008; Botha, 2004). However, an even more compelling view that I share is that principals cannot single-handedly lead transformation in schools (Peebles \& Hopstone, 2007, Harris, 2003b), or lead schools to greatness (Spillane, 2005). Kayrooz and Fleming (2008) opine that principals have no option but to distribute leadership throughout the school because of the many demands from different stakeholders and their ever increasing and unmanageable workload. This article recognises that, as in other organisations, leadership in schools resides in many people (Harris, 2003a), and that post-apartheid education policy emphasises teachers as agents of change (Gallie, Sayed \& Williams, 1997). It was on this basis that this article focuses on deputy principals in the context of collective leadership, not school principals in isolation. Lee, Kwan and Walter (2009) assert that the increasing focus on the leadership of transformation in schools does not go with an exponential increase in the focus on the role of deputy principals in the process. Besides, a focus on deputy principals is consistent with the increasing emphasis on collaborative leadership in schools, rather than on leadership based only on the formal authority and power of the principal (Gamage \& Zajda, 2005) [italics mine].

\section{Literature Review}

Educational leadership literature suggests that decentralised school management has become one of the key foci of school reform globally (Gamage, 2008; Richardson, 2007; Rodriguez \& Slate, 2005). In South African public schools decentralisation and shared decision-making are stipulated by the South African Schools Act, No 84 of 1996. Section 16 of this Act, entrusts the day to day management of schools to School Management Teams (SMTs), not individual principals in isolation. This article draws mainly on the work of Shields (2012 \& 2009) on transformative leadership. The espoused goals of transformative leadership theory cohere with South African post-apartheid education policy. The latter prescribes that transformation should help overcome the devastation of apartheid and provide an education system that builds democracy, human dignity, equality and social justice (Department of Education, 2001). These policy prescripts implore school leaders to ensure that schools are just, equitable and democratic in structure, processes and functions. They must show commitment towards the principles of sharing power, equality, equity, responsibility and well-being (Jahan, n.d.).

At the core of transformative leadership, which Shields (2012) insists is distinct from transformational leadership, is the notion of changing something (Shields, 2010; Foster, 1989; Jahan, n.d.). It is centred on seeking to understand and address issues of equity, diversity, social justice, and oppression, about which transformational leadership is often passive or silent (Shields in Kose, 2011). Transformative leadership is grounded in Freire's (2000) call for consientisation, critical reflection, critical analysis and activism (Shields, 2012). Whereas, the focus of transformational leadership is change within the institution, transformative leadership seeks to effect change beyond the organisation. It is therefore 
imperative that transformative leadership should start with the recognition of the material and social realities that engender inequality and marginalisation (Freire, 2000; Shields, 2010, 2009).

Peebles and Hopstone (2007) maintain that because it has social justice at its core, transformative leadership is highly applicable in urban schools. It can help address inequities, marginalisation and material conditions that militate against effective learning and teaching in township schools. A common view in this regard, is that transformative leadership should prioritise questions of justice and democracy, critique inequitable practices and question inappropriate use of power and privilege (Shields, 2010; Freire, 2000; Cooper, 2009; Theoharis, 2007; Dantley, 2003), and culminate in the creation of more democratic, equitable and effective institutions that differ from the unjust and dysfunctional status quo (Sturm \& Cantor, 2011). In the context of South African schools, Karlsson (2001) conceives of the goals of transformation as increased access, democratised structures and processes, redressing past inequalities and inequities, and improved efficiency. These goals should be pursued and realised in the realm of teaching and learning, governance and management, teacher development and support, and social relations.

According to Astin and Astin (2000) transformative leadership qualities required in a group context, like in an SMT, include collaboration, shared purpose, division of labour and ability to disagree with respect. This requires that school leaders should discard personal goals and ambitions in favour of a common vision and its associated goals. In concurrence, Kose (2011) argues that the development of a transformative vision is an important aspect of transformative leadership (Kose, 2011). Once there is consensus on what the school stands for and would want to be, such shared vision directs positive school change (Fullan, 2011), guides quality professional development (Tallerico, 2005) and, promotes equity and inclusivity (Scheurich \& Skrla, 2003; Riehl, 2000). This suggests that the shared vision should inform and guide the nature and trajectory of transformative school improvements. What ends on the transformation agenda, irrespective of where it originates, should become a concern for the collective. In this regard, Jahan (n.d.) maintains that transformative leaders infuse consultation and participation into organisational routines.

Transformative leadership does not in itself guarantee effective implementation of envisaged reforms. Brown (2006b) cautions that effective implementation of reforms depends on the motivation and capacities of local leadership for their success. There are also factors that operate independent of transformative leaders that may inhibit the implementation of reforms. Oakes et al, 2006 (cited by Sturm \& Cantor, 2011) opine that efforts to reduce inequality trigger conflict among people with unequal power and influence. A related view is that the major obstacle to any change comes from the dominant group who benefit from the current system (Jahan, n.d.). Brook Napier (2005) further notes that with regard to educational reforms developing countries face aggravated challenges and constraints which include, among others, resistance by teachers and other stakeholders; inadequate resources, inequitable distribution of resources; urban-rural differentials in needs and capacity, and corruption.

The emphasis of transformative leadership on the pursuit of democracy, consultation and participation points to an inextricable link between this practice and distributed leadership in schools. This view is supported by Cooper (2009) who argues that a collaborative ethos is necessary for transformative leadership. Distributed leadership, which is often used interchangeably with shared leadership, team building and democratic leadership, is a practice in which multiple leaders, followers and their situations interact (Kayrooz \& Fleming, 2008; Spillane, 2005). It is premised on the assumption that all school personnel can and must lead (Hopkins \& Jackson, 2003; Harris, 2003a), and that leaders can be drawn from all levels in the organisation, not just from the top (Williams, 2011; Kayrooz \& Fleming, 2008; Harris, 2005a). However, Williams (2011) cautions against viewing distributed leadership as a practice that displaces the principal. Rather, it should be viewed as inclusive and as fostering collaborative and ethical practice (Starratt, 2004). A distributed leadership perspective suggests that while the principals continue to be accountable for the day-to-day operations of schools, they ought to involve teachers in school decision making and implementation. It is commonly held and well documented that distributed leadership contributes positively to school effectiveness (Leithwood et al, 2004; Gronn, 2003). The focus of this article is on what deputy principals perceive as factors underlying the failure of transformative leadership in their township schools.

\section{Research Methodology}

\subsection{Research design}

To answer the research question for this study a qualitative research design was adopted. It allows the researcher to understand social phenomena from the participants' perspectives in their natural setting (McMillan \& Schumacher, 2006). The researcher used a multi case study which entails an intensive inquiry into instances of a phenomenon, seeking to 
understand it from the perspectives of the insiders - the researcher and respondents (Gall, Gall \& Borg, 2009). Merriam (1998) posits that such understanding is sought as a means for addressing critical problems and improving practice. In this study, it was envisaged that the design could help uncover deputy principals' perceptions of barriers to transformative leadership. This understanding was expected to culminate in improved leadership practice regarding school reforms.

\subsection{The sample}

The sample comprised of the four deputy principals from the two schools. The deputy principals were purposively included in the initial study because they are members of the School Management Team and the School's Executive Management Committee. As members of these committees and by virtue of their official positions of authority, they are involved in the day-to-day management of schools. It was thus a reasonable expectation that they would have some experience regarding the leadership of their schools. Only one of the four respondents had less than five years experience as deputy principal. He was in his first year of formal appointment to this position. He, however, had over 25 years teaching experience, and had more than ten years experience in various school leadership and management position, including a term as an acting principal.

\subsection{Data collection}

Data were collected through one-on-one semi-structured interviews that were about 60 minutes long. The duration was considered adequate as in-depth responses that were elicited covered the research question to the point of saturation and were supplementary to data from the initial study.

\subsection{Data analysis}

Data were transcribed verbatim from recorded narratives. Themes and subcategories were subsequently generated from the analysis following Tesch's steps for open coding (Creswell, 2007).

\subsection{Credibility measures}

The following measures were adopted to enhance the accuracy and credibility of the findings (Conrad \& Serlin, 2006; Saunders et al, 2000; Merriam, 1998):

- I did not bring my personal perspectives into the data or its analysis;

- The case study protocol and interview schedule were based on and guided by themes derived from extant literature;

- My tentative interpretation of data was referred to respondents to clarify uncertainties and to verify the accuracy and plausibility of findings; and

- I requested a colleague to comment on the findings in relation to the research questions and the study design.

\subsection{Ethical consideration}

This study was covered by the ethical clearance obtained from my employing university and permission granted by the Gauteng Provincial Department of Education. In addition, permission was obtained from the principal of each participating school before the commencement of the study. I explained the aim of the study to the respondents, they were assured anonymity and confidentiality, and they were informed that they could withdraw from the study or decline to answer some questions if they found a reason to do so. The narratives were tape-recorded with the express permission of the respondents. They were allowed to switch it off if they wanted to share some views "off-record" (Saunders et al, 2000).

\section{Findings and discussion}

Findings cohere with the view that blaming the principals increases when staff does not share management responsibilities (Gallie, Sayed \& Williams, 1997). Respondents had this perception about themselves and other roleplayers. Emergent themes from the analysis of data, which are discussed in detail below, are: bureaucracy and principals' accountability; inequity and staff divisions; teacher resistance; and, ineffective district office support. 


\subsection{Bureaucracy and principals' accountability}

The majority of the respondents considered the expectation that only principals should account to the Department of Basic Education (DoBE) to be the major contributory factor behind transformation challenges in their schools. They argued that principals use the power and authority of their formal positions to restrict other role-players - including them as deputy principals - from taking initiative and making decisions that can change the status quo. This applies even when envisaged changes would be only at their own level of operation, like the classroom. This practice of centralising changerelated decisions around principals ignores what Harris \& Townsend (2007) call the untapped resource of lateral leadership potential and energy. The nature and scope of school improvements and change, therefore, becomes restricted to what the DoBE prescribes, or what principals fancy and wish to enforce. In this regard, Grobler, Bisschoff and Beeka (2012) opine that, while principals are expected to discard their old forms of leadership and embrace collaborative leadership, they have no models to follow as the system remains essentially bureaucratic. All respondents acknowledged that from time to time their principals assign them and other staff change-related roles and responsibilities. Such assignments are, however, ad hoc, discretionary, and have to be carried out to the principals' specifications. This is consistent with other findings (Kwan, 2009). It is reportedly common for principals to demand explanations from, and scold deputy principals for making decisions that deviate from the given instructions, or what is deemed standard practice. To avoid possible humiliation, deputy principals claim they follow principals'orders to the letter or defer making decisions that imply changes in the absence of their principals. This exemplifies the bureaucratic bungling which, Grobler, Bisschoff \& Beeka (2012) assert, militates against innovation and quick decision making. The descriptors used by the majority of respondents to categorise their principals' leadership style support the view that they viewed their principals as barriers to transformation. These included, "too authoritarian", "kind off top-down", "less democratic", "bureaucratic" and, "old fashioned".

It was noteworthy that, consistent with other findings (Kwan, 2009; Lee, Kwan \& Walker, 2009) the majority of respondents reported that their school principals were reluctant to assign them tasks related to school finances or involve them in making related decisions. Subtle references to principals' financial mismanagement could be inferred from their responses. The problem with such perceptions, whether valid or not, is that they demotivate staff and make them reluctant to engage in other legitimate school initiatives. This stance was evident in this remark from one respondent, who had a qualification that included a financial management module:

Our principal uses the excuse that we are not members of the SGB [School Governing Body] to exclude us from making decisions that involve funds, even for our daily requirements. So, even those who know something about finances are unable to assist. We cannot introduce effective systems of procurement, working with suppliers, payments and keeping records. Personally, the closest l've got to finances is getting reports after expenditure, not deciding whether to spend, but it helps because one will not be blamed when it is discovered things are not going right...

\subsection{Inequity and staff divisions}

The two female deputy principals lamented that initially their age, experience and gender were covertly used to exclude them from shared decision-making on an array of issues. Unlike their older male counterparts, who were consulted regularly on almost all issues, they could not contribute their views regarding developments in the school. It was reportedly only when they questioned their marginalisation that their principals began to treat them with respect and consider their views. Such consultations, however, continue to be limited to those issues that principals feel comfortable about. Similarly, the two deputy principals think that they are only assigned those tasks that their principals do not want to execute. In the main, these are maintenance functions that involve no changes. One informative account in this regard was:

At first he would see this young girl who jumped from teacher to deputy principal and whose opinion did not matter. He related well and consulted the other deputy[principal], who was male and older...I had to build trust and show I am a strong woman who can be pushy and make things happen. It was only when I protested and he saw what I am capable of that he started to take me seriously. Lately, he is able to come to me and say, 'madam, how do we do this?'...

The female deputy principal of Alpha secondary school perceived the male deputy principal as complicit in, and as a beneficiary of the principal's dictatorship. She alleged that "these two men" colluded against her and excluded her from major decisions. She, therefore, did not find it unacceptable, "[to] resent and avoid working with the other deputy principal". While establishing the validity of these claims was beyond the scope of this study, it is clear that these perceptions in themselves suggest divisions that militate against transformation efforts. It is inconceivable that people can 
willingly collaborate with those they perceive as colluding dictators who seek to marginalise them. This view echoes Williams's (2011) sentiment that authoritarianism in South African schools is a barrier to creative interaction and deliberative discourse.

The negative impact of staff divisions was evinced by the two deputy principals of Alpha secondary school. They both conceded that teachers were divided on the basis of their loyalty to them. Contrary to the view that teacher leaders collaborate with colleagues to shape school improvement efforts and lead others to collective goals (Harris, 2003b), it was, reportedly, not easy for one deputy principal to get cooperation from teachers who are loyal to the other deputy principal at this school. This suggests that this specific school lacks what Harris (2005b) claims are the collegial norms among teachers which contribute to school effectiveness.

\subsection{Teacher resistance}

All respondents indicated that it was common in their schools for teachers to resist implementing mandatory change. Possible reasons they proffered for this included, perceiving the change as a top-down imposition, fear of the unknown and facing too many changes at a time. It is disturbing that the majority of respondents identified curricula change as the area that elicits resistance the most. This provides a possible explanation for the reported poor quality of teaching and learning and lower learner achievement in township schools (Jansen, 2013; Motala, 2011; Soudien, 2007). Teachers reportedly revert to their old ways of doing things, whenever they can, after attending workshops related to curriculum changes. Some male teachers in both schools were said to display sexist tendencies, that made it difficult for them to work harmoniously with female teachers, especially when the latter were assigned some supervisory or leadership responsibility over them. Such conduct flies in the face of the established fact that leadership is not the exclusive domain of any one person (Harris, 2003b). Interestingly though, is that, resisting the leadership of female staff, or school changes associated with them was reportedly not restricted to male teachers. This tendency was also displayed by some female teachers and male students. The latter became particularly difficult and uncooperative after completing the traditional ritual that initiates them into manhood. The majority of respondents pointed out that teachers who tended to resist change initiatives or being led by other staff, other than the principals, were generally also reluctant to assume leadership of committees or task teams. They did not want to do anything additional to their classroom teaching. This is untenable as it is practically impossible for principals to do everything and lead schools to greatness by themselves (Spillane, 2005).

\subsection{Inadequate support from the district office}

Respondents from both schools reported that the district office played a limited role with regard to helping transform schools. Contrary to the expectation that district offices should advance the implementation of quality education and improved service delivery (Department of Basic Education, 2011), district officials reportedly served only as links between schools and the DoBE. They merely forwarded information regarding envisaged changes in school programmes and procedures to schools. They did not initiate school-specific improvement programmes or address development needs of individual teachers. Their assistance in implementing school reforms was restricted to short training workshops whose limitations are well documented (Williams, 2011; Phorabatho, 2010, Saib, 2004). Notwithstanding this limitation, the two respondents from Omega secondary school reported that they had received extensive training in school leadership and management through funding from the Department of Basic Education facilitated by the district office. The two schools were reported to be unable to organise their own workshops because of limited financial resources.

The majority of respondents maintained that parents were enthusiastic to support developments in the school. Although the majority of parents were impoverished, not literate and could not support the school financially, they were always willing to assist in kind, by volunteering their time and labour to change the social and material conditions in the school. A common view of the respondents was that it was the failure of the district office to capacitate parents to undertake their SGB tasks with understanding and confidence which compromised their effectiveness. Instead of parents taking the lead and deciding the direction which the school should take, it was argued, they followed the direction and pace determined by the principal. Transformation in these schools is thus perceived as stifled by the unsophisticated nature of parent participation, not low levels thereof as commonly held (Mangena, 2012; Motala, 2011). One comment in this regard was:

Our school cannot change and grow because the principal dominates everything. He dictates to the SGB pretending to give them advice based on policies of the department. Thereafter, he dictates to the SMT claiming he represents the wishes of the parents. So everything is about him and it brings conflict between parents and teachers. Parents would 
not support him if the IDSOs [District officials] were doing their job and providing relevant training to the SGB...

The failure of these schools' site-based leaders to introduce and lead transformation validates the view that schools may not succeed to restructure themselves on their own without the support of other stakeholders (Moyo, 2005). It is sad though, that the district office being the immediate external stakeholder fails to fulfil that mandate.

\section{Conclusion}

This paper examined factors which account for the failure of township secondary schools to be lead to transform, as perceived by deputy principals. In the main, failure to lead schools to transform is blamed on the principal's authoritarianism and related practices. However, arguing from a distributed leadership perspective, no role-players are completely blameless. The majority seem to understand the transformation role as an add-on to their prescribed teaching and administrative responsibilities, which can be ignored or deferred to others. Although pertinent, respondents' concerns about the principals' leadership styles are general concerns that could possibly be raised even if the subject was not transformation. Nothing suggests that the schools have some common values or vision regarding transformation which could be used to frame the transformation agenda, or as the basis for determining staff commitment to transformation. Other staff members also display attitudes and practices that militate against collective leadership for transformation. Instead of collaborating towards common goals, staff remains positioned as adversaries. Transformation is unlikely to be led effectively in these schools as their key features identified by the respondents - unauthentic democratic environment; resistance; holding on to hierarchical power; and, deferring or shrugging leadership responsibility - militate against distributed leadership (Woods, 2005). The status quo entrenches principals as arbiters of the transformation agenda and gives little hope that the schools can be led to transform effectively. Clearly, and contrary to their mandate, district officials are ineffective in overseeing the transformation of township schools. It would be helpful for schools if they can begin to conceptualise school transformation in the context of whole-school development, not a whimsical handling of issues in isolation. Transformation must be driven through an open agenda with known deliverables and timelines. This stands to be realised if all role-players have a common understanding of what constitutes democratic governance and how it should permeate their day-to-day exercise of their roles and responsibilities.

\section{References}

Astin, A.W., \& Astin, H.S. (2000). Leadership reconsidered: Engaging higher education in social change. Battle Creek, MI: W.K. Kellogg Foundation. Botha, R.J. (2004). Excellence in leadership: Demands on the professional school principal. South African Journal of Education, 24, $239-243$.

Brook Napier, D. (2005). Implementing educational transformation policies: Investigating issues of ideal versus real in developing countries. In D.P. Baker, \& A.W. Wiseman (Eds.), Global Trends in Educational Policy (International Perspectives on Education and Society), 6, 59-98.

Brown, K. M. (2006a). Leadership for social justice and equity: Evaluating a transformative framework and andragogy. Educational Administration Quarterly, 42(5), $700-745$

Brown, K. (2006b). "New" educational injustice in the "new" South Africa". A call for justice in the form of vertical equity. Journal of Educational Administration, 44(5), 509-519.

Cooper, C.W. (2009). Performing cultural work in democratically changing schools: Implications for expanding transformative leadership frameworks. Educational Administration Quarterly, 45(5), 694-794.

Conrad, C.F., \& Serlin, R.C. (2006). The SAGE Handbook for Research in Education: Engaging Ideas and enriching Enquiry. Thousand Oaks: SAGE.

Creswell, J.W. (2007). Qualitative inquiry and research design: choosing among five approaches (2nd ed.). Thousand Oaks, CA: SAGE.

Department of Basic Education (2011). Guidelines on the Organisation, Roles and Responsibilities of Education District Departments. Pretoria: Government Printers.

Department of Education, 2001. Education change and transformation in South Africa: A review 1991 - 2001. South African Government: Pretoria.

Freire, P. (2000). Education for critical consciousness. In M.A Freire \& D Macedo (Eds.), The Paulo Freire reader (pp.80-110). New York, NY: Continuum.

Fullan, M.G.(2011). Leading in a culture of change. San Francisco, CA: Jossey-Bass.

Gall, M.D., Gall, J.P., \& Borg, W.R. (2009). Applying educational research: How to read, do, and use research to solve problems of practice (6 $6^{\text {th }}$ ed.). Boston, MA: Pearson Education.

Gallie, M. Sayed, Y, \& Williams, H. (1997). Transforming educational management in South Africa. Journal of Negro Education, 66(4), 460-467.

Gamage, D.T. (2008). How did school-based governance lead to distributed leadership, partnership and improved student learning? Journal of the Centre for Research in Secondary Schools, 7, 27-41.

Gamage, D.T. \& Zajda, J. (2005). Decentralisation and school-based management: A comparative study of self governing school models. Educational Practice and Theory, 27(2), 35-58.

Grant, C. (2006). Emerging voices on teacher leadership. Educational Management Administration and Leadership, 34, 551-532.

Grobler, B., Bisschoff, T. \& Beeka, A. (2012). Changing perceptions of teachers regarding the importance and competence of their principals as leaders. South African Journal of Education, 32(1), 40-55.

Gronn, P. (2003). The new work of Educational Leaders: Changing Leadership Practice in an era of School Reform. London: Sage Publishing.

Guskey, T.R. (2002). Professional development and teacher change. Teachers and Teaching: Theory and Practice, 8(3 \& 4), 381-391.

Harris, A. (2005a). Foreword. In D. Woods. Democratic Leadership in education. London: Paul Chapman Publishing.

Harris, A. (2005b). Distributed leadership. In Davies, B (Ed.), The essentials of school Leadership. London: Corwin Press. 
Harris, A. (2003a). Introduction. In A. Harris, D. Hopkins, M. Hardfield, A. Hargreaves \& C. Chapman (Eds.), Effective Leadership for School Improvement. London: Paul Chapman Publishing.

Harris, A. (2003b). Teacher leadership as distributed leadership: heresy, fantasy or possibility? School Leadership and Management, 23(3), 313-324.

Harris, A. \& Townsend, A. (2007). Developing leaders for tomorrow: releasing system potential. School Leadership and Management, 27(2), $167-177$.

Hopkins, D. \& Jackson, D. (2003). Building the capacity for leading and learning. In Harris, A., Hopkins, D., Hadfield, M., Hargreaves, A. \& Chapman, C. (Eds.), Effective leadership for school improvement. London: Routledge Falmer.

Jahan, R. (n.d.). Transformative leadership in the $21^{\text {st }}$ century. [Online]. Available at: htpp://www.capwip.org/resources/wompa/conf2000/downloads/jahan/ pdf.(20 February 2013)

Jansen, J. (2013). Our matric results and schooling: two ways of doing the maths. Sunday Times Review, 2013, January 06.

Karlsson, J. (2005). Transformation in the school environment - an analsysis of photographs from one rural secondary school. In Transformation of the South African schooling system. Johannesburg: CEPD.

Karlsson, J. (2001). Review of South African Policy. In M Kgobe (Ed.). Transformation of the South African schooling system. (pp.139-177). Johannesburg: CEPD.

Kayrooz, C. \& Fleming, M.J. (2008). Distributed leadership: Leadership in context. Paper presented at the UNESCO-APEID International Conference: Quality Innovations for Teaching and Learning. 08-09 December, 2008. Bangkok, Thailand.

Kose, B.W. (2011). Developing a transformative school vision: Lessons from peer-nominated principals. Education and Urban Society, 43(2), 119-136.

Kwan, P. (2009). The vice-principal experience as preparation for the principalship. Journal of Educational Administration, 47(2), 191-205.

Lee, J.C., Kwan, P., \& Walker, A. (2009). Vice-principalship: their responsibilities, roles and career aspirations. International Journal of Leadership in Education, 12(2), 187-207.

Leithwood, K., Jantzi, D., Early, L., Watson, N., Levin, B., \& Fullan, M. (2004). Leadership for large scale reform: the case of England's national literacy and numeracy strategy, School Leadership and Management, 24(1), 57-79.

Mafora, P. 2013. Learners' and teachers' perceptions of principals' leadership in Soweto secondary schools: a social justice analysis. South African Journal of Education, 33(3) [online]

Mangena, M. (2012). Demobilised education parenting. AZAPO e reng? 2012, March 06.

Mathonsi, V. (2001). Transforming governance and management of education. The case for South Africa. Paper presented at the South African Democratic Teachers' Union National Policy Conference, 17-21 April 2001. Midrand.

McMillan, J.H., \& Schumacher, S.S. (2006). Research in Education: Evidence-based inquiry (6 th $^{\text {ed.). }}$. Boston: Pearson.

Merriam, S.B. (1998). Qualitative research and case study applications in education. San Francisco: JosseyBass.

Mokonyane, N. (2011). Address by the Premier, at the Soweto Education Summit, Johannesburg, 09 April 2011. [Online] Available: http://www.polity.org.za/article/gp-mokonyane (March 3, 2012).

Moloi, K.C. (2010). How can schools build learning organisations in difficult education contexts? South African Journal of Education, 30, 621-633.

Motala, S. 2011. The great classroom debate. The Star, 2011, December 13.

Moyo, G. (2005). Change agents in South African schooling system Challenges and prospects. In Transformation of the South African schooling system. Johannesburg: CEPD.

Msila, V. (2009). School choice and inter school migration: Black parents scrambling for quality education in South Africa. Journal of Education, 46, 81-98.

Msila, V. (2005). The education exodus: The flight from township schools. Africa Education Review, 2, 173-188.

Pandor, N. (2006). Speech by Minister of Education, Naledi Pandor MP, at the SADTU Conference, Johannesburg, 2006 September 01.

Peebles, L.D., \& Hopstone, T. (2007). Transformative leadership for diverse learning communities: Redefining the role of professional learning communities in urban schools, In S. Donahoo \& R.C. Hunter (Eds.) Teaching leaders to lead teachers: Advances in Educational Administration, 10, 313-329.

Phorabatho, T.A. (2010). Managing the implementation of the National Curriculum Statement in Moretele secondary schools. Med dissertation. Pretoria: University of South Africa.

Richardson, A.M. (2007). The future of site-based management: Principals are key. Academic Leadership, 5(3), 1-7.

Riehl, C.J. (2000). The principal's role in creating inclusive schools for diverse students: A review of normative, empirical, and critical literature on the practice of educational administration. Review of Educational Research, 70, 55-81.

Rodrigues, T.A. \& Slate, J.R. (2005). Site-based Management: A review of the Literature. [Online] Available at http://www.usca.edu lessays/voll52005/slate2.pdf. (07 February 2013).

Saib, M. (2004). The role of the Senior Management Team in managing Outcomes-Based Education assessment. Med dissertation. Pretoria: UNISA

Saunders, M., Lewis, P., \& Thornhill, A. (2000). Research for Business Students. ( $2^{\text {nd }}$ ed.). Essex: Pearson Education Limited.

Scheurich, J.J., \& Skrla, L. (2003). Leadership for equality and excellence. Thousand Oaks, CA: Corwin Press.

Shields, C.M. (2012). Transformative leadership in education: Equitable change in an uncertain and complex world. New York: Routledge.

Shields, C.M. (2010). Transformative leadership; Working for equity in diverse contexts. Educational Administration Quarterly, 46, 558-589.

Shields, C.M. (2009). Courageous leadership for transforming schools: Democratising practice. Norwood, MA: Christopher-Gordon.

Soudien, C. (2007). The "A" factor: Coming to terms with the question of legacy in South African education. International Journal of Educational Development, 27, 182-193.

Spillane, J.P. (2005). Distributed leadership. The Educational Forum, 69(2), 143-150.

Starratt, R.J. (2004). Ethical leadership. San Francisco, CA: Jossey Bass.

Sturm \& Cantor (2011). Transformative leadership for a more just society: Revitalising Higher Education's role. Ford Foundation White Paper.

Tallerico, M. (2005). Supporting and sustaining teachers' professional development: A principal's guide. Thousand Oaks, CA: Corwin Press.

Theoharis, G. (2007). Social justice educational leaders and resistance: Toward a theory of social justice leadership. Educational Administration Quarterly, 43, 221-258.

Van Deventer, I., \& Kruger, A.G. (2008). An Educator's Guide to School Management Skills. Pretoria: Van Schaik.

Van Wyk, N. (2007). The rights and roles of parents of parents on school governing bodies in South Africa. International Journal about Parents in Education, 1(0), 132-139.

Villegas-Reimers, E. (2003). Teacher Professional Development: An International Review of the Literature. Paris: UNESCO International Institute for Education Planning.

Williams, C.G. (2011). Distributed leadership in South African schools: Possibilities and constraints. South African Journal of Education, 31, 190-200.

Woods, P.A. (2005). Democratic leadership in education. London: Corwin Press. 